\title{
“FAILED INTERVIEWS'
}

\section{DOING TELEVISION HISTORY WITH WOMEN}

\author{
Dana Mustata \\ University of Groningen \\ Research Centre for Media and Journalism Studies \\ Oude Kijk in 't Jatstraat 26 \\ 9712EK Groningen \\ The Netherlands \\ D.Mustata@rug.nl
}

\begin{abstract}
This article zooms into the practice and historiographical implications of doing television history with women. Drawing primarily upon interviews with women having worked at Romanian television during communism, the article develops a conceptual understanding of 'feminine voices' as primary sources into television history. It situates these gendered historical sources within historiographical practices of accessing neglected, marginalized or silenced areas in television history, in other words, the 'blind spots' in the medium's history.
\end{abstract}

Keywords: women; television under communism; television historiography; marginalized histories.

\section{Introduction}

What do we gain by giving a voice to women in the writing of television histories and what would the practice of becoming inclusive of feminine voices in television historiography actually entail?

"What's up with this one? Make her disappear", burst out Elena Ceausescu - dictator Nicolae Ceasescu's wife - in response to seeing one of the continuity announcers sporting a new haircut on the screen back in $1985 .{ }^{1}$

"My image on the screen at the time meant: 'I am full of life, I exist, I do not have heating in my home, the city is grey, there seems to be no future, we get to see less and less of the world beyond the walls that have been fencing us in, but I am alive, I smile and I exist", responded the same continuity announcer, remembering the haircut that sent Elena Ceausescu in rage. ${ }^{2}$

"I am fed up with people in this country thinking they can write a history of Romanian television", a former Romanian television employee said to me as she struggled with the bitter-sweet remembering of her own youth 
that she spent working in a broadcast institution, that limited the freedoms of its employees, while fostering the growth of a professional culture that more often than not felt like a family to the people on the inside. ${ }^{3}$

"I will leave this institution with nostalgia, or better said, with pain, sadness and frustrations", confessed to me former news editor and continuity announcer Carmen Movileanu as she shared her feelings about the social stigma that has been attributed to the Romanian public broadcaster in the aftermath of Ceausescu's dictatorship. ${ }^{4}$

In my research on the history of Romanian television under communism, female interviewees invited me into their homes, spoke about their private lives as television professionals, shared feelings, expressed anger, fear and passion as part of their remembering. Through their oral histories and life stories, these women offered access to a historical context that remained unarticulated by most of the male interviewees. It was primarily through the clashes, confrontations, denials and rejections that took place between me, as an outsider and women as direct participants to history that I have learnt to hear the silences and the unspoken in the history of a broadcast institution that emerged and matured during a repressive political regime.

This article focuses on doing television history with women and attempts to theorize the historiographical practices and implications of that. It draws upon empirical data such as oral history interviews with current and former television professionals at Romanian Television (TVR), autobiographic memoirs and published interviews in the media. The empirical focus of the article - the context of TVR during communism - is relevant for the discussions at stake here. As a geopolitical area that until less than a decade ago has been neglected and at best, marginalized in television history, the case of television under communist regimes opens up broader incentives and understandings of how to tackle neglected, marginalized or silenced narratives in the writing of television histories: 1) it offers roughly unfamiliar grounds on which mainstream television histories can be rendered unfamiliar and challenged; 2) it draws attention to lacks and silences in television histories and historiographies; 3 ) it brings to the fore tensions and contradictions in television history prompted by the repressive context in which television in this geopolitical area unfurled; 4) last, but not least, it confront us television historians - with going beyond the comfort zone of our mainstream historiographical practices.

The article will start off by situating the practice of doing television history with women within existing television historiographies that have in one way or another focused on women. I will call these 'gendered television historiographies', so as to claim the focus on women making a specific contribution to the historical understanding of television. I will continue with unpacking the methodological implications of doing television history with women, asking how we can give voice to women as primary sources in television history and what that practice may actually entail. I will then zoom into three thematic 'blind spots' in the study of television history, which came to the fore through my dialogue with female interviewees at TVR and my struggles with hearing what these women had to say as they rejected, confronted or denied talking to me. This is an explorative article attempting to bring issues of gender and femininity in dialogue with discussions on historical sources and television historiography.

\section{Gendered Television Historiographies}

\subsection{Women and Television History}

The study of women in television history has been an area with an established tradition. The domestic and intimate nature of television as a communications medium lent itself naturally - and rather problematically - to the study of

3 Interview with former female television producer at Romanian Television (TVR), Bucharest, January 2008. For reasons of privacy, the identity of the interviewee remains undisclosed.

4 Personal interview with Carmen Movileanu, Bucharest, 8 April 2016. 
cultures of femininity. Women on the screen offered insights into gender-biased modes of representation that have reproduced feminine norms and values in our societies. ${ }^{5}$ Women as viewers offered access to the domestic household as the context for studying television audiences and understanding the gender power relations inherent to television viewing. ${ }^{6}$ Women who have worked in television broadcasting offered insights into the medium's political economy and the power relations unfurling on the work floor. ${ }^{7}$ Other television scholars have looked at women's television as a genre and programming strategy. ${ }^{8}$

Rather than looking at women as an object of study in the first place, this article will speak about women - whether on the screen, in front or behind the screen - as primary voices in television history. The question that will be at the forefront of discussions here is: 'what kind of television histories do we gain access to by giving a voice to women in the writing of television histories?' The women in question are not necessarily female television scholars writing secondary historical accounts of television, but rather women that featured as first-hand participants and witnesses to the historical parcour of television; in other words, women that can offer primary insights into television histories. This article is about doing television history with women to paraphrase Rachel Moseley, Helen Wheatley and Helen Wood who wrote about histories of television for women, distinguishing their work from histories of television by or about women. Doing television histories with women raises primarily methodological and historiographical questions. The issue at stake here is about integrating women's narratives into the writing of television histories, arguing that women's voices offer access to alternative histories of television by serving as tools for harvesting marginalized or neglected narratives of the medium and eliciting new modes of writing television histories. While historical studies of television that have focused on women have inevitably relied on women's accounts and experiences of television in the weaving of their narratives, this article takes discussions further to ask:

- What other narratives of television - other than histories of or about women themselves- can we gain access to by giving voice to women in television?

- How can we best give voice to women in the writing of television histories, a medium wherein women have been assigned secondary positions?

It is perhaps no coincidence that in television historiography, it is primarily - yet not exclusively ${ }^{9}$ - female television scholars who have put on the map television histories dedicated to women, as evidenced also by the bulk of the works in this article. To give just a few examples, the founding members and coordinators of the Women's Film and Television Network in the UK and Ireland have been exclusively female. Similarly, it was female scholars such as Rachel Moseley, Helen Wheatley and Helen Wood who set up and let the project 'A History of Television for Women in Britain, 1947-1948', which resulted in the edited collection 'Television for Women: New Directions'. On another front, Anikó Imre ${ }^{10}$ wrote about socialist television for women, while Sonja de Leeuw and Dana Mustata ${ }^{11}$ wrote about continuity announcers as neglected professionals in television history. Other female television scholars, such as Amanda Lotz ${ }^{12}$ among others established themselves also through their feminist contributions to television scholarship.

5 Julie D’Acci 'Television, Representation and Gender', The Television Studies Reader, Robert C. Allen, Annette Hill, eds, Routledge, 2004, pp. 373-389; Mary Ellen Brown, Televsion and Women's Culture. The Politics of the Popular, Sage, 1990; Charlotte Brunsdon, Julie D'Acci, Lynn Spigel, eds, Feminist Television Criticism. A Reader, Oxford University Press, 1997.

6 David Morley, Family Power: Cultural Power and Domestic Leisure, Routledge, 1986; Ellen Seiter, Hans Borchers, Gabriele Kreutzner, and Eva-Maria Warth, eds, Remote Control: Television, Audiences and Cultural Power, Routledge, 1989.

7 Ruth McElroy, 'The feminisation of contemporary television drama: Sally Wainright and Red Production', Rachel Moseley, Helen Wheatley and Helen Wood, eds, Television for Women: New Directions, Routledge, 2017, pp. 34-53; Vanessa Jackson, '"Women pushed their way forward and became quite a force within the BBC": women's roles in television production and the production of television for women', Rachel Moseley, Helen Wheatley and Helen Wood, eds, Television for Women: New Directions, Routledge, 2017, pp. 53-73; Vicki Meyer, Miranda J. Banks, John T.

Caldwell, eds, Production Studies: Cultural Studies of Media Industries, Routledge, 2009.

8 Rachel Moseley, Helen Wheatley and Helen Wood, eds, Television for Women: New Directions, Routledge, 2017; Anikó Imre, 'Television for Socialist Women', Screen, Vol. 54, Issue 2, Summer 2013, pp. 249-255.

9 See the work of Alexander Badenoch, co-founder of the Women's Radio in Europe network.

10 Anikó Imre, 'Television for Socialist Women', Screen, Vol. 54, Issue 2, Summer 2013, pp. 249-255.

11 Sonja de Leeuw, Dana Mustata, 'In-Vision Continuity Announcers. Performing an Identity for Early Television in Europe', VIEW Journal of European Television History and Culture, Vol. 2, Issue 4, p. 51-67.

12 Amanda Lotz, Redesigning Women: Television After the Network Era, University of Illinois Press, 2006. 


\subsection{Doing Television History With Women}

As previously mentioned, the core discussion here is one that has methodological and historiographical ramifications. The driving question is: how can we integrate neglected narratives - of women, in this case - into television histories and how can we do that without reproducing the antagonisms between dominant and marginal discourses, mainstream and alternative histories, centers and peripheries? How can we unearth these narratives in all their fullness, messiness, tensions and richness without filtering them through the lens of these dominant dichotomies?

In television history, women have for the most part been relegated to secondary positions, while the study of women has been approached through the logic of binarism. This has positioned women against dichotomous understandings of femininity versus masculinity, low culture versus high culture, fictional versus factual programming, private versus public sphere, passive viewing versus active deliberation, gossip as associated to drama versus the serious talk of news. Under this logic, feminine identities have been scrutinized through television genres - e.g. soap operas,$^{13}$ drama, ${ }^{14}$ participatory daytime talk shows ${ }^{15}$ - that have traditionally been ascribed to lower cultural categories. ${ }^{16}$ On the production floor, women have been predominantly looked at through workplace hierarchies, ${ }^{17}$ which inevitably reiterated the antagonisms between exploiters and the exploited. The very notion of television scheduling - as John Ellis ${ }^{18}$ explains - has a history of being based on traditional values of femininity, mirroring the dominant ideology of a nuclear family with stay-at-home mothers and working fathers. In fact, television itself - as an intimate medium connected to the private sphere - has been regarded as 'feminine', as opposed to cinema that is situated in the public sphere and subject to a masculine gaze that is 'fixed, controlling and uninterruptable'. ${ }^{19}$ While there is value in calling out the second-class positions that have been assigned to women in television and in the writing of television history, this paper aims to broaden discussions about the place of women in television historiography by going beyond the logic of binarism, which as Trinh Minh-ha (1998) argued, serves to reproduce the logic of domination. ${ }^{20}$

Several television scholars with a feminist agenda have already attempted to rectify and bring nuance to the roles that women have been assigned in television history. Rachel Moseley, Helen Wheatley and Helen Wood have reclaimed 'women's television' as a cultural category in its own right - calling it a 'rescue project' - by theorizing and historicizing it as a genre and programming strategy closely tied to female personnel, whose richness and value have underpinned important cultural and social shifts. ${ }^{21}$ In the edited collection, 'Television for Women: New Directions' (2017), contributors have pointed out to cult television drama as a platform for intervening into gendered identities and redefining hierarchies of taste, ${ }^{22}$ they've looked at women's television as a symptom of shifting perceptions of female

13 Christine Geraghty, Women and Soap Opera: A Study of Prime Time Soaps, Polity Press, 1991.

14 Julie D'Acci, Defining Women: Television and The Case of Cagney and Lacey, University of North Carolina Press, 1994.

15 Jane M. Shattuc, The Talking Cure: TV Talkshows and Women, Routledge, 2014

16 Jason Mittell, 'Audiences Talking Genre: Television Talk Shows and Cultural Hierarchies', Journal of Popular Film and Television, 31(1),

pp. 36-46; Jason Mittell, 'A Cultural Approach to Television Genre Theory', Cinema Journal, Vol. 40, No. 3, Spring, 2001 , pp. 3-24.

17 Julie D’Acci 'Television, Representation and Gender', The Television Studies Reader, Robert C. Allen, Annette Hill, eds, Routledge, 2004,

pp. 373-389; Mirand J. Banks, 'Gender Below-The-Line: Defining Feminist Production Studies, Vicki Meyer, Miranda J. Banks, John T. Caldwell,

eds, Production Studies: Cultural Studies of Media Industries, Routledge, 2009, pp. 87-99.

18 John Ellis, 'Scheduling: The Last Creative Act in Television?', Media, Culture and Society, Volume 22, Issue: 1, pp. 25-38.

19 Clarlotte Brunsdon, 'Women Watching Television', MedieKultur, Vol. 2, No. 4, 1986, p. 105.

20 Trinh Minh-ha, Woman, Native, Other: Writing Postcoloniality and Feminism, Indiana University Press,1989.

21 Rachel Mosely, Helen Wheatley, Helen Wood: 'Introduction: why 'television for women', Screen, Volume 54, Issue 2, 1, June 2013,

pp. 238-243.

22 Dana A. Heller, 'Catfight! Camp and queer visibility in Orange is the New Black, Rachel Moseley, Helen Wheatley and Helen Wood, eds,

Television for Women: New Directions, Routledge, 2017, pp. 73-90. 
identities, ${ }^{23}$ as an instrument for interfering with feminist politics ${ }^{24}$ and have painted a more nuanced picture of the professional roles that women have played in the history of television production. ${ }^{25}$ The 'Television for Women Dossier' published in Screen in 2013, which includes the work of several other television scholars with a feminist agenda - such as Anikó Imre, Julia Hallam, Hazel Collie, Mary Irwin, Lynn Spiegel - took these discussions even further by reclaiming the cultural values and social function of 'television for women' in different national, regional and generational contexts.

This article contributes to 'rescuing' women in television history and historiography, by focusing on women as participants to television history and their voices in narrating the history of the medium. This is an interventionist project meant to claim the multiplicity of voices, positions and understandings in television history, which co-exist within a heterogeneous framework of knowledge defined by contradictions, messiness, paradoxes and tensions; a framework of knowledge that goes beyond the binary oppositions that have only reinforced and reproduced the dominant, while keeping the dominated on the margins of television scholarship.

Borrowing from the postcolonial and feminist work of Trinh Minh $\mathrm{Ha},{ }^{26}$ this article showcases women in television as voices of hybrid television histories, the term 'hybrid' referring to histories wherein hierarchies of knowledge are dissolved, boundaries between what counts as historical sources and voices of authority in historical storytelling are undone, while space is created for new forms of knowledge and for narratives that may refuse to lend themselves to consensus-based interpretative frameworks pertaining to institutionalized histories, so as to remain 'free-floating', 'unfixed' and 'discontinuous'. ${ }^{27}$

While the article focuses exclusively on women's voices, it argues that these voices are associated to cultures of femininity, which are not limited to women only. Male interviewees and eyewitnesses also contribute to what I will coin as 'feminine voices' in television historiography.

Giving voice to women in television asks for new practices of doing television history. Such practices would act against appropriating women's voices within dominant discourses of television history - 'a pseudo-science of appropriating Otherness or a mere stir within the same frame' as Trinh Minh-ha (1992) calls it ${ }^{28}$ - and instead, introduce these voices as multivocality, a multivocality that challenges, breaks and overthrows existent boundaries within the discipline. So is the practice of 'speaking nearby' as opposed to 'speaking about' women in television. 'Speaking nearby' is an anthropological practice introduced by Trinh Minh-ha in her documentary film 'Reassemblage' (1983). As Minh-ha points out, it is a way to 'make visible the invisible', a form of 'indirect language' that 'does not objectify, does not point to an object as if it is distant from the speaking subject or absent from the speaking place. A speaking that reflects on itself and can come very close to a subject, without however, seizing and claiming it. ${ }^{29}$ The result of it is the provision of an entry point into absences, silences, conflicts and contradictions and a point of departure for cultural - and in this case, historiographical - reflection. As the focus of this article is on speaking and voice, I have chosen to make hardly any use of visual material in the discussions here. This is to stay away from attempts of objectifying the female interlocutors that have served as inspiration for this article, while focusing on my own practice of 'speaking nearby' them. At the same time, the quotes transcribed are long and carry the signs of indirect speech.

23 Vicky Ball, 'Sex, Class and Consumerism: British Sitcom's negotiation of the single girl', Rachel Moseley, Helen Wheatley and Helen Wood, eds, Television for Women: New Directions, Routledge, 2017, pp. 128-149.

24 Sujita Moorti, 'Brown girls who don't need saving: social media and the role of 'possessive invetment' in The Mindy Project and The Good Wife, Rachel Moseley, Helen Wheatley and Helen Wood, eds, Television for Women: New Directions, Routledge, 2017, pp. 90-110.

25 Vanessa Jackson, "Women pushed their way forward and became quite a force within the BBC": women's roles in television production and the production of television for women', Rachel Moseley, Helen Wheatley and Helen Wood, eds, Television for Women: New Directions, Routledge, 2017, pp. 53-73.

26 Trinh Minh-ha, 'Woman, Native, Other: Writing Postcoloniality and Feminism', Indiana University Press, 1989. See also Trinh Minh-ha's documentary film 'Reassemblage. From the Firelight to the Screen', 1983.

27 Victor Buchli, An Archaeology of Socialism, Berg, 1999.

28 Nancy N. Chen, "'Speaking Nearby:" A Conversation with Trinh T. Minh-ha', Visual Anthropology Review, Vol. 8, No. 1, Spring 1992,

pp. 82-91, p. 85.

29 Idem, p. 86-87. 


\section{Speaking Nearby: Women as Primary Voices in Television History}

In my practice of interviewing staff who have worked at Romanian Television (TVR) during communism, few types of behaviour stood out among female interviewees: they preferred to conduct their interviews in their private homes; they expressed emotions during or before committing to the interviews, and last, but not least, they were much more receptive to life stories interviewing techniques than to semi-structured oral interviews. These types of behaviour may at a first glance - be well too easily connected to cultures of femininity that are closely tied to emotionality, the realm of the home and the private sphere as well as to sharing of personal stories as a communication practice. However, much more than speaking about what may distinguishes female from male interviewees - a line of reasoning that is not of interest here and which would in fact, reiterate the same logic of binarism that runs at the core of mainstream television historiography - these types of behaviour exhibited during the interviews delivered upon analytical inspection unexpected, silenced or neglected historical insights. It is this that I want to focus on here.

\subsection{Trauma and Social Stigma as Neglected Phenomena of Post-Socialist Television Broadcasters}

It was through the indirect language of emotionally charged responses that I have got to learn about the pains and traumas of former staff of Romanian television who have worked inside the institution during communism. Indirect language that is produced by 'speaking nearby' refers rather to 'an attitude in life, a way of positioning oneself in relation to the world. ${ }^{30}$ It is a practice of going beyond the spoken words, making the way words are spoken a point of inquiry so as to understand the absences and silences that lie beneath.

It was when interviewees wouldn't speak to me about their past professional life at TVR, when they refused to answer my questions and gave me hours of stories I did not ask for and which I would dismiss at a first glance as irrelevant to my own research that I could access the spaces of silences and absences that these responses were emerging from. I initially labeled these experiences as 'failed interviews.'

My first 'failed interview' was four hours long. It consisted primarily of what I then classified as 'gossip' from the 1960s that painted the artistic scene in Bucharest at the time and the social circles some of the TVR employees would be active in. It was a type of talk that I initially dismissed for not having enough factual grip to it for historical research. The interviewee ${ }^{31}$ was a female programme maker and producer of entertainment programmes in TVR and had been active in the institution since the 1960s.

Prior to committing to the interview, we talked on the phone. She asked me where I was based as a researcher, why I was interested in writing about Romanian television and questioned why a Dutch institution would be interested to finance research about Romanian television history. Upon hearing my answers, she retorted: 'We used to have great television under communism, one of the best in Europe. There is no person yet able to write the history of this institution' she said, referring to TVR. After a pause and a change in tone, she added in a softer voice: 'We were not allowed to travel abroad before '89. You get to do your research on Romanian television at a university abroad.'

As we met face-to-face, she started the interview by saying: 'I will tell you what I want to tell you and not you or the people in the Netherlands ${ }^{32}$ want you to write about.' She spoke about TVR having been a school for learning

30 Idem, p. 87.

31 Due to the sensitive nature of discussions in section 3.1 and the fact that the interviewees did not openly and directly talk to me about their traumas, I will not reveal the interviewees' identity. This interview was carried out in January 2008 in Bucharest.

32 At the time of conducting the interview and carrying out my research, I was affiliated to a Dutch university. 
television making, a place where other television professionals who went on to work for private channels after 1989 learnt how to make television programmes and how to film for television. 'The great television programmes we used to have, have been replaced by nudity and cheap entertainment after 1989. Private channels are full of them,' she continued. She then started to reminisce about her own youth back in the 60s. She started working in TVR straight after graduating from university, she remembered the people she studied with, the people she socialized with, among them artists, musicians and other colleagues from TVR. She spoke about the theatre plays they would attend and the films they would see in the cinema. 'Alain Resnais films were being shown in cinemas around Bucharest a week after being premiered in Paris,' she remembered. 'You could find Paris Match at newsstands around the capital.' All this spoke about Romania's opening to the West in the 1960s, a phenomenon well documented by history books and other historical sources. ${ }^{33}$ The closest one could get to the West was through cultural imports that found their way into cinemas, to newsstands and on television. ${ }^{34}$

Much more than that, our dialogue spoke about a woman's youth spent under a regime that wouldn't allow young people to travel abroad; it spoke about the nostalgia and the emotionally charged remembering associated to that: nostalgia for the loss of one's youth that coincided with a culturally rich and politically permissive period of Romanian television, and the painful remembering of 'missing out' on liberties that were taken away by the political regime. Her contrasting between the 'now' and the 'then' - the cheap entertainment and the televised nudity of the 'now' versus the high quality and politically provoking television programmes of times past - speaks in defense of what was lost and what was lost was the 'great television we used to have', as she put it. The way she related to me as a historian of Romanian television - a subject matter that to her meant her own youth - points to a generational and professional gap between 'them' as the ones who have lived through that history of isolation and 'us' who are distant from that lived past (as distant as coming from the West!). 'There is no person yet able to write the history of this institution' she said and with this, she took a stand against historians attempting to appropriate a past that - beyond historical facts of what happened - comes wrapped in the living cultures of one's professional youth; the living cultures made up of a 'complex whole which includes knowledge, belief, art, morals, law, custom, and any other capabilities and habits acquired by man [n.a. and woman] as a member of society', as the anthropologist Edward Burnett Tylor defined it more than a century ago. ${ }^{35}$

This line of reasoning positions histories of television personnel and labour within the backdrop of lived cultures of the past, bringing television historiography close to anthropology: the anthropology of otherness in television, wherein otherness is represented through an unattainable, distant and long-gone past; through what remains unarticulated and left out by factual histories; and - in the case of former socialist broadcasters in Europe - through a demised political context that molded other ways of life and work. This anthropological take on television's lived professional cultures positions the television of the past as a 'society' on its own that at the very least can sensitize historians to being reflexive of and accounting for any practices of appropriation, whether it's appropriation into mainstream narratives or dominant discourses of television historiography.

In this context, it is perhaps not paradoxical perhaps that it is through women as 'secondary' and oftentimes 'marginalized' members of this past televisual 'society' that we get to access this otherness. Nor is it paradoxical perhaps that - during my interviewing experiences - it was women who called out this otherness through their emotional responses and justified refusals to talk.

33 See also Dana Mustata, 'Television in the Age of (Post)Communism: The Case of Romania', Timothy Havens, Aniko Imre, Katy Lustyik, eds, Popular Television in Eastern Europe During and Since Socialism, Routledge, 2013, pp. 47-64.

34 The 1960s was the most permissive period in Romanian television, a period where entertainment and social programmes in the form of 'reportages' could still get away with critiquing the political power, when The Saint was imported from ITV, together with American cartoons and films. This happened against the backdrop of Ceausescu consolidating his new power and regime of independence from the Soviet Union. For more detailed discussions of Romanian television during this period, see Dana Mustata, 'Television in the Age of Postcommunism', 2013 and Dana Mustata, 'The Power of Television. Including the Historicizing of the Live Romanian Revolution', PhD Dissertation, Utrecht University, 2011.

35 Edward Burnett Tylor, Primitive Culture: Researches into the Development of Mythology, Philosophy, Religion, Language, Art, and Custom, John Murray, 1871, p.1. 
'I don't want to partake in political talk' said a female former programme maker and producer of theatre shows ${ }^{36}$ someone who has made numerous contributions to the history of TVR through her television programmes and as editor of a number of publications dedicated to the history of the institution - as she politely declined to be interviewed about her own professional career inside TVR and the role and conditions of female employees inside the institution during communism. She continued to justify her refusal to talk: 'The media has written a lot about the politics of Romanian television under television. Speaking about those times inevitably involves talking about politics. I am retired now and I want to enjoy my retirement in peace.'

'I wouldn't have anything new to add to what has already been written about me in the media and maybe I'm not the best person to talk about women and TVR under communism', apologized modestly another female maker of music programmes, who - through her extensive career in TVR - has become an illustrious name on the musical scene in Romania. ${ }^{37}$

It was the emotions that my inquiries into the history of Romanian television stirred within female interviewees - much more than what was spoken - that carried deeper meanings into what it was like being a young television professional in Romania at the time. An interview that I initially deemed to be a 'failed interview' on Romanian television history turned out to be an eye-opening discussion with a female television professional decrying her lost youth marked by wounds of cultural isolation and restricted freedom. The discussion helped paint the human context of professing within a cultural branch - such as television broadcasting - that was defined by isolation from Western culture and where freedom of movement - whether in the form of travelling, professional exchanges or the flow of ideas - was strictly monitored and restricted. Beyond these already known facts, ${ }^{38}$ what these talks with former female TVR professionals brought out in the open is the trauma and pains of a professional past that still lingers into present-day post-socialist societies. The fact that this is not an issue of the past that can easily be dismissed as traumatic and painful remembering is corroborated by the fact that almost thirty years after the collapse of communism in Romania, TVR still carries the stigma of its own political past through the way the institution has been covered ever since in the media as an outdated broadcaster with a long tradition of political servitude. This is also strongly signaled by attitudes of being defensive that have perspired through my interviews, attitudes of current and former TVR personnel taking a defensive stand for the professional history of the institution, its history and with it, their own lived experiences; attitudes taken against the backdrop of the constant criticism coming from the rest of the media. Other women I have spoken to, confessed their pains regarding the social stigma that has been inflicted upon the institution since 1990. As Carmen Movileanu said:

I am close to retirement and I will leave this institution with nostalgia, or better said, with pain, sadness and frustrations. Too many people out there have done their best to demonstrate to us (n.a. TVR employees) that we are not good enough, that it is our fault, that it is us who cannot do our jobs well, that we are incapable of doing so and that it is us who cannot adjust. ${ }^{39}$

No television historian has yet looked into the lingering traumas and pains of former socialist broadcasters in Europe. The article argues that is through female television professionals that we can begin to access these neglected and silenced phenomena of television's socialist past; phenomena that have affected both male and female former staff.

\subsection{The Female Censor: Elena Ceausescu}

Attempting to understand the role of women in television history, the case of Romanian television under communism brings with it insights into a less known professional role: the role of the censor.

36 To respect the privacy of person involved, her name is not revealed here. The conversation took place on the phone in January 2018.

37 Idem.

38 See: Dana Mustata, The Power of Television: Including the Historicizing of the Live Romanian Revolution, PhD Dissertation, Utrecht University, 2011.

39 Personal interview with Carmen Movileanu, Bucharest, 8 April 2016. 
Mainstream television histories have located television censorship within the sphere of institutional politics, regulation and policy. The tightening of censorship in Romanian television during communism, for instance, is to be traced back to 1971, when TVR became part of the Radio and Television National Council, which fell under the direct supervision of the Central Committee of the Communist Party. In 1973, at the head of the Council was named the secretary of the Party's Central Committee - Cornel Burtica - a move, which aligned Romanian television closer to political structures of the Party. Other people from the dictator's personal entourage, such as his son Nicu Ceausescu - was also elected as member of the Radio and Television Council. ${ }^{40}$

Censorship practices inside Romanian television took the form of 'screening sessions' (transl. 'vizualizari') that all programmes had to undergo before going on air. Politically approved programmes received so-called 'visas', which meant the right to be broadcast. In the aftermath of these screening sessions, programmes were either forbidden for broadcasting, or strict indications were given for politically sensitive and seemingly problematic scenes to be edited out before broadcasting. Then there was self-censorship as another form of controlling potentially undesired content in TVR. 'We knew what we could broadcast and what not, and the worst censors became some of our colleagues in our department,' confessed former programme maker Stefan Dimitriu. ${ }^{41}$ 'TVR professionals knew how to do their job at times of censorship. They got away with doing their own thing, by knowing how to play around with the rules of what was allowed and what was not allowed', confessed Carmen Movileanu, former news editor. ${ }^{42}$ This institutionalized form of censorship targeted any potentially deviant or defiant messages on television, whether such messages appeared through the spoken commentaries, or through visuals. Texts to be read out during live broadcasts, for instance, also needed to be pre approved by censors. 'Everyday I came into work I would receive a stack of papers', remembered Silvia Ghiata Ciurescu, who started out in TVR in 1971 as a continuity announcer, to later on become a programme maker and TVR producer. ${ }^{43}$

'The text was irrelevant, it was pretty much the same text all the time' she continued, referring to what she had to read out live on television as a continuity announcer.

It was not the text that puzzled me, but the five stamps each piece of paper had on it, each stamp indicating the political filters and 'visas' that the text had undergone [...]. I was obliged not to change in any way the original intended meaning of a sentence.

I was very nervous before going live on air. I was in a state of constant stress, which looking back was not healthy for me. I was stressed first of all knowing that I was not allowed to step outside of the boundaries of what I supposed to say and to do. I was also stressed knowing that I had to treat the camera as if it was a person standing in front of me - easier said, than done. But mostly was stressed by the sounds around me. Next to me there was a secured window and opposite it, there was the control room. We could hear after the live broadcasting through the window if the editor-in-chief would call in - there was a short 'bing' sound accompanying those phone calls. When the President of TVR would call, there was a longer 'bing' sound. When that happened, we knew that we made a major mistake. All these sounds and the stress of it all caused anxieties in me [...]. I was 22-23 at the time. [...] And there was something else. For every mistake we made, we had a $5 \%$ or a $10 \%$ cut in our salaries for a week, depending on the gravity of it. The long 'bing' sound that announced a phone call from the TVR president, meant a 10\% cut from our payment in the next month.

But there was also the banning of television professionals from the screen, from continuity announcers to sports commentators. Behind this banning stood the personality of Elena Ceausescu, the dictator's wife. In colloquial

40 For a more elaborated discussion on this, see: Dana Mustata: 'A History of Power: Stories of Romanian Television', The Power of Television: Including the Historicizing of the Live Romanian Revolution, PhD Dissertation, Utrecht University, 2011.

41 Personal interview with Stefan Dimitriu, Bucharest, January 2008.

42 Personal interview with Carmen Movileanu, Bucharest, 8 April, 2016.

43 Personal interview with Silvia Ghiata Ciurescu, Bucharest, 15 January 2018. 
language, she was referred to as 'the Comrade from Office no. 2', a jargon term alluding to her political power and her position as second-in-command. 'Office no. 2 had become even more frightening than Office no. 1', argued historian of Romanian communism, Vladimir Tismaneanu. ${ }^{44}$

Sports commentator Cristian Topescu remembers how he was kicked off the air and sacked from TVR after a live commentary during a football match between Romania and Sweden, in which he said that Romanian football players, who had offers from foreign clubs, should be allowed to play abroad, as this would benefit the Romanian Football Federation and Romanian football in general:

The Prime Minister at the time called 'the Comrade from Office no. 2' and told her: 'Topescu has encouraged the Romanian youth to emigrate abroad." 'The comrade from Office No. 2 answered: "Kick him out of TVR". 45

It was Elena Ceausescu who decided in the 1980s that the only faces that would appear on television were the faces of the news presenters and of the continuity announcers. Reporters could no longer be presented fully on camera, at best only their hand holding up the microphone could be shown. ${ }^{46}$

One time [n.a. in the 1980s] after I was live on air, the president was calling the control room incessantly. Everyone looked at me asking what I had done. I told them, I had done nothing, I showed them the text that I was supposed to read out, which I followed strictly. It turned out he was calling because I was wearing a dress made by Romartizana that was identical to one owned by Elena Ceausescu. It was not my fault. I went to Romartizana and the women there recommended the dress to me as being superb. I had to change dresses immediately and I was forbidden to wear it again. I wasn't punished for the incident as it wasn't my fault, perhaps the staff at Romartizana suffered the consequences - they knew they had only made two dresses of that kind. That incident caused madness in the studio.

Another colleague of mine, Delia Budeanu [n.a. another continuity announcer at the time], had a more rebellious character. After she got married to Radu Budeanu, she became even more rebellious. Radu encouraged her, saying: 'what can they do to you?' So she changed her hairdo: she got a haircut with a prominent fringe, she looked like Cleopatra, she put on strong makeup, wore red lipstick. She was a brunette with blue eyes. She was beautiful! The editor-in-chief let her go on air like that. I don't know the discussions that took place afterwards, but after appearing like that on television, she was sent to present on the radio for a while, that was another form of punishment that was applied to us. ${ }^{47}$

In her book 'Live', Delia Budeanu spoke about the incident:

The haircut resembled the one that Catherine Zeta-Jones wore in Chicago. In 1985 such haircuts were spread subliminal [n.a. pro-Western] anti-communist slogans on the screen [...]. When she saw me, Elena Ceausescu screamed: "What's up with this one? Make her disappear.' I only returned to present on television after 10-11 months on the condition that I changed my haircut. ${ }^{48}$

Elena Ceausescu - the active participant in television censorship among the dictatorial couple - introduced another practice of censorship in Romanian television. It was the most direct form of censorship - one that emerged from the private sphere of the dictatorial couple and mirrored their viewing practices and tastes. Elena Ceausescu's

44 Vladimir Tismaneanu, 'Biografia necunoscuta a Elenei Ceausescu. Cine a fost de fapt, Tovarasa de viata si de lupta a Dictatorului', Evenimentul Zilei, 18 August 2013.

45 Nicoleta Zaharia, 'Elena Ceausescu: “Dati-I afara pe Topescu din TVR!”, Historia

46 Brates, 1992, p. 17.

47 Ibid

48 Delia Budeanu, Live, 2008, p. 22 
interference with television broadcasting was done by means of a 'short phone line'. It was a short telephone number assigned to the dictatorial couple. Any phone calls from that number alerted the TVR employees that they were receiving orders or admonishments from the highest level. She called in anticipation of programmes, asking for last-minute changes in the programme schedule. She also called in the immediate aftermath of a programme that displeased either her or Nicolae Ceausescu in one way or another.

The censorship measures that Elena Ceausescu applied to television programmes and television personnel no longer followed strict guidelines and institutionalized regulatory measures. They mirrored personal tastes, insecurities, jealousies and conflated egos that belonged to the private sphere of the dictatorial couple and which played a key role in engineer their personality cult in the 1980s. Often at times, they emerged out of scorn and personal vendettas. Famous in this case is the life story of Romanian actress Violeta Andrei who was forbidden by Elena Ceausescu to appear on television and was denied acting roles by her superiors on Elena's orders. ${ }^{49}$ The story goes that the dictator's wife had strong feelings against the beautiful, elegant and talented actress, who was at the time married to Stefan Andrei, Minister of External Affairs at the time.

Elena Ceausescu's direct involvement in censoring television serves as a case study that opens up yet another neglected area of study in television history: the role of the female censor and censorship as situated within the private realm of emotionality.

\subsection{Women in Television as Symptomatic of Hybrid, Non-Linear Television Histories}

The previous discussion on Elena Ceausescu as a television censor not only points to a neglected profession in television history - one that emerges from the marginalized area of socialist television history - but it also points out to the diverse roles that women have played in television history.

This diversity of roles becomes even more interesting from a historiographical point of view when it resurfaces as co-existent and concomitant - at times contradictory and paradoxical - experiences of television, a phenomenon that takes a step away from consensus-based dominant discourses of television history and calls upon non-linear and non-hierarchical histories of the medium. I argue that it is through their multi-faceted relations to and experiences of television that women's oral testimonies and life stories speak of, which can offer access to these non-linear histories of television.

Firstly, their professional parkour in television mirrored a fluid movement through different television professions. Starting with early television history, women climbed up the ladder and changed jobs within the same institution. The 'feminine' professions inside Romanian television under communism - by which I mean the professions predominantly populated by women and which does not - were the ones of continuity announcers and editors in charge of television montage. These professions provided a springboard for later career shifts that offer insights into the versatile contributions to women to television history.

'The profession of continuity announcer was a beautiful profession, which I very much enjoyed. But I became an actual television professional when I started making programmes', remembered Silvia Ciurescu Ghiata who started out as a continuity announcer in 1971 and in 1986 she was encouraged by Tudor Vornicu - programme director at the time - to start making programmes herself. She described the experience as starting out from scratch within the same institution she had already been active in for more than a decade. 'I was pushed out of working as a continuity 
announcers because of a health problem, I could no longer have the television lighting reflecting onto my face and into my eyes. That's when Tudor Vornicu told me:

Silvia, you are able to make television programmes. Have confidence in yourself. Remember that you can do this. Look, tomorrow I'll assign the big studio for you to work in for three days and I want you to make Toamna cu Vivaldi (transl. 'Autumn with Vivaldi')'. [...] Bring a friend with you, take a stage manager to brainstorm with, the cameramen you want and you can make Toamna cu Vivaldi any way you want. [...] I eventually made a fourteen-minute programme. [...] Afterwards Tudor Vornicu came to me, hugged and told me "I knew you could do it". ${ }^{50}$

After 1990, Silvia Ghiata Ciurescu continued to make cultural programmes dedicated to dancing, such as Lumea Dansului ('The World of Dance') and later on, became a television producer of successful programmes, such as Mari Romani ('Great Romanians'). Ciurescu's professional trajectory in TVR is not of a unique kind. Carmen Movileanu, another female TV professional started out as an editor for the news department. ${ }^{51}$ In 1990, she was encouraged by another female television maker Cornelia Radulescu, to compete for one of the openings for continuity announcers. She was a continuity announcer until 1998, when the profession faded out from the broadcast institution, after which she continued as a programme maker in the entertainment department.

Women such as Ruxandra Garofeanu, an art critique and television professional who had dedicated herself to making programmes about art in TVR since 1972, defined themselves through their professional versatility. When asked to define her professional career, Ruxandra Garofeanu acknowledged: 'I was both, an art critic and a television professional, but first and foremost I was an art critic and what l've done in television was through my passion for and expertise on art. ${ }^{52}$

Women in Romanian television under communism were expected to and trained to have versatile professional skills. As Silvia Ciurescu Ghiata confessed: 'I joined television after graduating from the choreography school. When I started working as a continuity announcer, I was asked to go study journalism and I did. During my undergraduate studies in journalism, I've learnt many beautiful subjects, such as 'World History', and among them, there were also the obligatory courses on politics or political economy'. ${ }^{53}$

Historiographically, this professional versatility that women in TVR displayed serves as a vantage point into looking at 'feminine' broadcast professions as multi-positional, wherein women have concomitantly occupied diverse professional identities, navigated a variety of skills and areas of expertise, moved through different departments and in doing so, they've and constantly redefined their relations to their co-workers and those in power.

This multi-positional professional space that women have occupied in Romanian television under communism becomes an area of research that is conducive to accessing 'the grey areas' of television under socialism and the negotiations of power that took place.

This multi-positional professional space is by no means exclusive to women, however, I argue that it has been rendered most visible by women and through 'feminine' television professions such as that of the continuity announcer, which became a springboard for further career advancement, dissolved and transmuted into other professions.

The multi-positionality of women's professions in TVR corroborates well with the diversity of social roles that women played in relation to television. From Elena Ceausescu's position as a female censor to female construction workers

50 Personal interview with Silvia Ghiata Ciurescu, Bucharest, 15 January 2018.

51 Personal interview with Carmen Movileanu, Bucharest, 8 April 2016.

52 Personal interview with Ruxandra Garofeanu, Bucharest, 16 January 2018.

53 Personal interview with Silvia Ghiata Ciurescu, Bucharest, 15 January 2018. 
depicted on the construction site of Television Centre in Bucharest at the end of the 60s (see figure 1 and 2), women working in TVR occupied co-existing social roles.

They were citizens expected to live by example, especially female television professionals with visibility on the screen such as continuity announcers.

As a continuity announcer, I was expected to show integrity in my personal social life outside TVR. [...] Our editor-in-chief would tell us: "You are five continuity announcers in the whole country. Everyone knows who you are, even in the most remote regions of the country. So you are not allowed to go out dressed inappropriately." [...] It was looked down upon to go and drink in bars, for instance. Of course, abiding by all this was a matter of one's character. I had colleagues, who wouldn't care much when they went out. It was in my character to do the proper thing. [...] I would go to the market to buy tomatoes, for instance, wearing make-up and having proper attire, remembered Silvia Ghiata Ciurescu. ${ }^{54}$

Women in TVR were also mothers as well having a demanding profession and they were expected to balance out the two roles: 'I was on air until I was eight months pregnant and returned to work two months after I gave birth. [...] It was a period when several continuity announcers got pregnant around the same time', reminisced Silvia Ghiata Ciurescu. Later on, as a mother whose husband ${ }^{55}$ was often abroad a lot, Silvia found herself in the position of providing for her children while being on constant call for TVR. 'There were situations in which I was called back to work from holidays, while being away or alone with the children at time. After the earthquake in 1977, my husband was abroad and I was
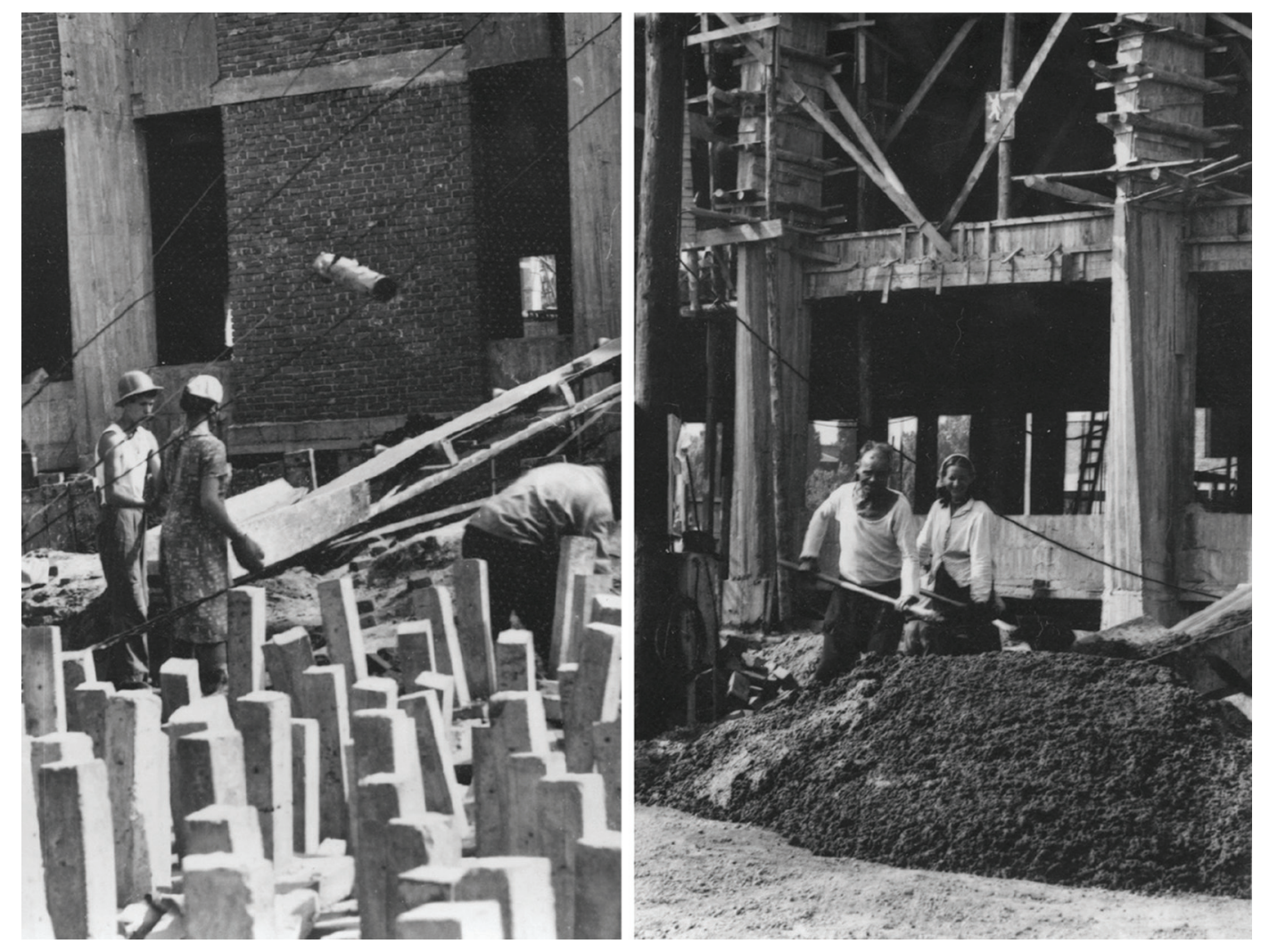

Figures 1 and 2. On the construction site of the Television Centre in Bucharest. CTVR.

54 Idem.

55 Ilie Ciurescu, former adjunct editor-in-chief for external affairs news, who frequently joined Ceausescu's visits abroad as part of his role within TVR. 
with the children at home. I got a phone call early in the morning to come to TVR and open the transmission at 10am. I walked to TVR and I left the children with my mother-in-law'. ${ }^{56}$

Women's fluid transitions through different television professions and the balancing out of different social roles points out to professional hierarchies in television as being unfixed and open for change. It shows television professions and professional identities as being multi-layered and singles out women as mediators of television's fluidity between private and public spaces: the private spaces of the home, of motherhood and the working mother as well as the private spaces of emotionality and reactivity associated to television viewing as exemplified by the censorship acts of Elena Ceausescu; the public spaces of professional labour, social and political citizenship. It is the co-existence and concomitance of these multi-faceted dimensions of television that women in television help signal, that makes female television professions symptomatic of - and by extension, an entry point into - hybrid and perhaps non-linear narratives in television history.

\section{Conclusions}

Treating women as primary sources in television history brings our attention to gendered entry points into historical narratives and the contributions these make to our understanding of television history. They offer insights into 'feminine voices' as primary historical sources that help render visible the 'blind spots' in television history marked by silences, lacks, contradictions, tensions and messiness. Feminine voices as primary historical sources reside primarily in the realm of expressive - at times confrontational - encounters with lived histories. They come to surface through denials, rejections, misunderstandings between the historian and her subject of study, through the blurring of boundaries between private stories and professional histories, the merging of television's public and private spheres as well as through the historian's coming out of her comfort zone. Such feminine primary voices in television history are not restricted to women only.

Integrating feminine voices in television historiography brings about questions of (mis)appropriation of television's other cultures, remote times and distant political, social and generational contexts. It sensitizes historians to reflect on their practices of inclusion and exclusion, in itself an act conducive to 'rescuing' neglected narratives of television history and redeeming these from the margins of the discipline. It is perhaps no coincidence, for instance, that the emerging area of (post)socialist television history in Europe has been pioneered predominantly - albeit not exclusively ${ }^{57}$ - by female television scholars ${ }^{58}$, as the case of European (Post)Socialist Television History Network illustrates.

Feminine voices in television history bring to surface television's cultural otherness, an otherness represented by other times, other generations, other regions and more often than not, professional cultures defined by other 'languages' and practices than historian's own craft, to paraphrase Marc Bloch. ${ }^{59}$ This acknowledgement of television's otherness may help put historians out of their comfort zone and inspire them to look outside their own set of historiographical practices to borrow instruments of understandings from other disciplines, such as anthropology, feminist or postcolonial studies. The added value of all this is the direct contribution to developing the conceptual and analytical tools to unearth neglected phenomena, professions and narratives in television history and restore them into a more inclusive television scholarship, one which collapses the logic of binarism that runs at the core of mainstream television histories.

56 Personal interview with Silvia Ghiata Ciurescu.

57 Among others Lars Lundgren and Ferenc Hammer have been among the co-founding members of the European (Post)Socialist Television History Network, a research platform aimed at harvesting marginalized or neglected histories of (post)socialist television in Europe.

58 Such as Anikó Imre, Sabina Mihelj, Irena Reifova and myself.

59 Marc Bloch, The Historian's Craft, Manchester University Press, 1954. 


\section{B i o graph y}

Dana Mustata is assistant professor in Media and Audiovisual Culture at the Research Centre for Media and Journalism Studies, University of Groningen, the Netherlands. She is co-founder of the European (Post)Socialist Television History Network and led the collaborative project 'Television Histories in (Post-Socialist) Europe' (2013-2016). She is the principal investigator of the project 'Everyday matters. Material Historiographies of Television in Cold War Europe', funded by the Netherlands Organization for Scientific Research (NWO). She is co-chair of the Media Studies Commission of the International Federation of Television Archives FIAT/IFTA. 